\title{
Combined effect of land use/cover types and slope gradient in sediment and nutrient losses in Chancho and Sorga sub watersheds, East Wollega Zone, Oromia, Ethiopia
}

\author{
Tolera Megersa ${ }^{1 *}$, Dessie Nedaw ${ }^{2}$ and Mekuria Argaw ${ }^{1}$
}

\begin{abstract}
Background: The use of existing land use/cover type exerts more pressure on the natural dynamism of the watersheds and hydrology due to continued cultivation and mis-management of land resource. The objectives of this study was to assess the combined effects of land use/cover types and slope gradient on watershed hydrology in terms of sediment and nutrient losses/transport from HRU of each land use/cover types. Integrated soil and water assessment tools (SWAT) model with Arc-GIS was used for simulation of sediment and nutrient loss by using land use/cover, soil, slope and climatic data as input. Analysis of variance (ANOVA) for mean comparison and correlation was used for data analysis.

Result: Combined effects of urban land and slope gradient produced more sediment than other land use/cover types followed by cultivated land. In cultivated land as slope gradient increased values of sediment and nutrient losses also increased until it reaches to 30\% slope and then declined. In Forest and grassland sediment loss increased until 15\% slope then after declined, but in urban land as slope gradient increases sediment and nutrient loss are also increased.

Conclusion: Cultivated land and difference in its slope gradient had more significant effect on watershed dynamics and hydrology in terms of loss of fertile top soil from upland, downstream water quality reduction and sedimentation of water structures than others land use/cover types and need to avoid steep slope and continuous cultivation and implementing integrated watershed management strategies in order to keep the natural dynamism of the watersheds.
\end{abstract}

Keywords: Land use/cover, Slope gradient, SWAT, Watershed dynamics

\section{Background}

Agricultural based economy and rapidly increasing human population are the main cause of land use-cover change in the developing countries (Tufa et al. 2014). Resource scarcity and fast population growth will force people to encroach steep lands, shrub lands and forests to satisfy their food production (Hamza and Iyela 2012). These land use-cover change have significant influence

\footnotetext{
*Correspondence: toleramegersa@gmail.com

${ }^{1}$ Center for Environmental Science, Addis Ababa University, Addis Ababa, Ethiopia

Full list of author information is available at the end of the article
}

on quantity or quality of stream flow (Bewket and Sterk 2005). Different studies that have been carried out in many parts of Ethiopia indicated that croplands have expanded at the expense of natural vegetation, forests and shrub lands (Kassa and Gerd 2007). The Land usecover change has negative consequence in hydrological system of a sub basin (Legesse et al. 2003).

Expansion of agriculture, urbanization, deforestation and the day to day activities of mankind resulted to temporal and spatial change in land use land cover have affected water flow path ways and water balance. Developing countries like Ethiopia, where there agriculture 
serves as backbone of the economy and ensure wellbeing of the people; the adverse effects of land use land cove change are diverse. Beside to this various water resource development sectors (hydropower, irrigation, urban and rural water supply etc.) have persistently been affected by both temporal and spatial changes of LULC (Nigusie and Yared 2010).

The major effects of land use/cover change are likely to alter the hydrologic response of sub basin and change in water availability (Setegn et al. 2011). The Land cover under little vegetation is subjected to high surface runoff and low water retention (Tufa et al. 2014). Whereas, the high vegetation covers increase, evapotranspiration and decrease the mean annual river flow. The Land usecover plays a fundamental role in driving hydrological processes within a sub basin (Gwate et al. 2015). These include changes in water demands such as irrigation, changes in water supply from altered hydrological processes of infiltration, groundwater recharge, and runoff, and changes in water quality from agricultural runoff (Mengistu et al. 2009). Therefore, a far better understanding of land use-cover change, its effect, and interaction to the hydrology of a basin is highly essential.

SWAT is a semi-distributed and physically based watershed model that operates at a continuous time-step (Arnold et al. 1998). The model is designed to simulate the effects of changes in the catchment management practices on surface water and groundwater hydrology, diffuse pollution and sediment erosion within catchments (Taylor et al. 2016). Two kinds of data; spatial data and temporal data are required by SWAT model. Spatial data include a digital elevation model (DEM), land-use map and soil map. The temporary data include hydrological data (stream flow and sediment yield) and climatic data (precipitation, solar radiation, relative humidity, wind speed and temperature). Within SWAT, a catchment is divided into multiple sub-catchments which are then further divided into Hydrologic Response Units (HRUs) that consist of homogeneous land use, slope and soil characteristics. The simulation processes of watershed using SWAT are split into two phases: as (i) land-based phase and (ii) routing phase (channel-based phase). The landbased phase controls the loadings like runoff, sediment, nutrient and pesticides. While, the channel based routs the loadings throughout the stream network (Sam et al. 2016).

Chiang et al. (2010) assessed individual impacts of land use change and pasture management on sediment, $\mathrm{N}$, and P losses with SWAT2009. With 12 years of detailed spatial land use data, they differentiated the impacts of land use change from conservation practice implementation. They used these results to determine the relative contribution of sediment and nutrients from pastureland, including the impacts of land application and intensive grazing, and urban areas, and demonstrated the importance of modeling in pollutant source identification. Tuppad et al. (2010) simulated field-scale and watershedscale reductions in runoff, sediment, total $\mathrm{N}$, and total $\mathrm{P}$ from several structural and non-structural man-agreement practices using APEX, a field-scale model that has similar functions as SWAT and has recently been linked to SWAT (Gassman et al. 2010).

Sediment and nutrient loss estimation of each land use/ cover types in Sorga sub watershed under different slope gradient was not yet studied. Therefore, the study aimed to assess the combined effects land use/cover type and slope gradient on sediment and nutrient losses in a study watershed.

\section{Methods and materials} Study area description

The research was undertaken at Chancho and Sorga sub watersheds in East Wollega Zone, Oromia, Ethiopia. East. Wollega is located at the distance of $328 \mathrm{~km}$ from Addis Ababa along the main road from Addis Ababa to Asosa (Fig. 1).

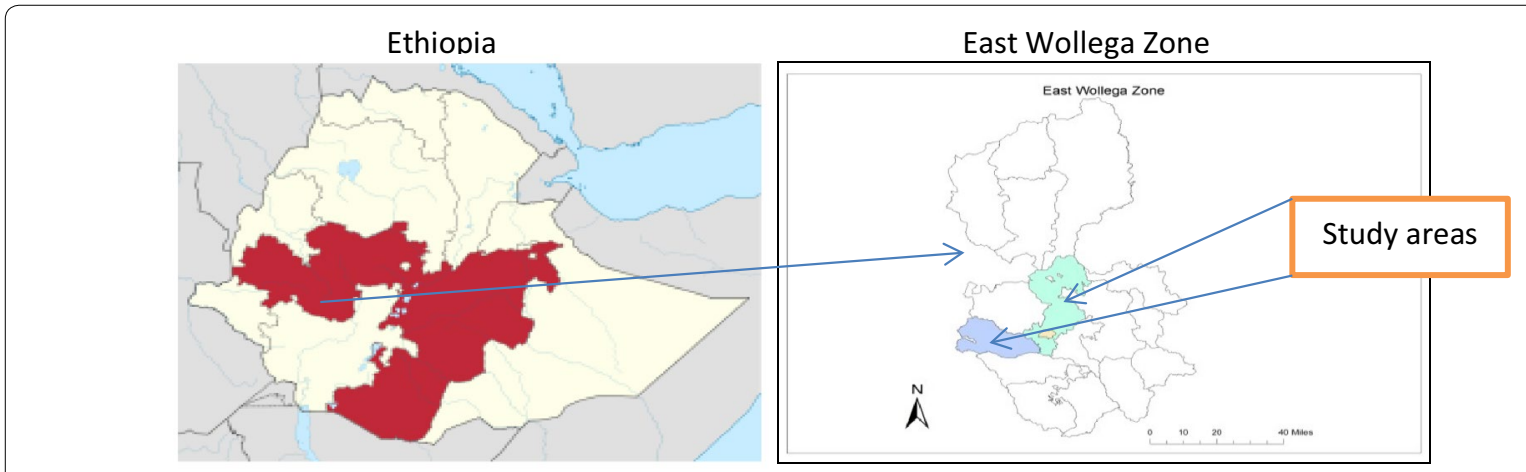

Fig. 1 Map of the study area 


\section{Description of the study sub-watershed}

The watersheds delineation were carried out using $30 \mathrm{~m}$ DEM loaded to Arc SWAT version 2.3.4 and SWAT version 2012 on ArcGIS 10.3 platform. The watershed delineation process consists of five major stages such as DEM setup, stream definition, outlet and inlet definitions, watershed outlets selection, definition and calculation of sub-basin parameters. The size of sub-basin in the watershed will affect the assumption of homogeneity. Hence, the definition of a watershed, sub-basin boundaries and streams is decided based on a threshold area to define streams, using a threshold value, the Chancho sub watershed was delineated into 17 and Sorga sub-watersheds into 21 sub-basin (Fig. 2).

Chancho sub watershed is found in Diga District at $15 \mathrm{~km}$ from Nekemte town to the West. It is located at $9^{\circ} 01^{\prime} \mathrm{N}$ and $36^{\circ} 28.2^{\prime} \mathrm{E}$ at about $2 \mathrm{~km}$ from Diga Town. The total area of the watershed including the water bodies is 2109 ha out of these 250 ha of the land is covered by water. The watershed lies between 2100 and 2260 m.a.s.l. The dominant land use/cover type in both watersheds is cultivated land followed by forest and water bodies in Sorga and Chancho sub watersheds, respectively. This sub watershed was used for SWAT model calibration purpose.

Sorga sub watershed is found in Guto Gida bordering partly Diga District, East Wollega Zone, Oromia. It is located in Western part of the region along the main asphalt road Nekemte to Asosa. The total area of a watershed is $3817 \mathrm{ha}$, of this reservoir occupies 30 ha of land including the buffer zone and Neqemte town which is partial in Sorga sub watershed occupies 326 ha of land. Altitude range of Sorga sub watershed is 21002260 m.a.s.l. This sub watershed was selected for SWAT model validation and subsequently details simulation of water quality parameters.

\section{Slope classification of the study watersheds}

Topography is defined by a digital elevation model (DEM), which describes the elevation of any point in a given area at a specific spatial resolution as a digital file. DEM is used to analyze the drainage pattern of the watershed, slope, stream length and width of channel within the watershed. The DEM used in this study was obtained from the Oromia Water Resources Bureau, Ethiopia with a spatial resolution of $30 \mathrm{~m}$. Slope gradient of the study watersheds are classified into five classes. Almost 70\% and $65 \%$ of Sorga and Chancho sub-watershed slope classified under steep to very steep slope land $(8-15 \%$ and $15-30 \%$ ), respectively, (Fig. 3). Distribution of this slope classes to each land use/cover indicated that, $85 \%$ of cultivated land in both sub watersheds classified under steep to very steep slope but more of steep slope lands were under cultivation. Forestland accounts for $87 \%$ of steep to very steep land, in which very steep land share is higher than steep land. 95\% of urban and grass land of the study area are also classified under steep to very steep land (Table 1).

\section{Climate}

The climate of the study watersheds is moderately cool representing typical medium (moist middle altitude) agro climatic zone. Altitude in the watersheds ranges from 2100 at the valley bottom to 2260 m.a.s.l at the peak of Southern hills. The recorded climatic data of Nekemte and Leka Dulecha meteorological station for 37 years includes; annual rainfall, max and minimum temperature, relative humidity, wind speed and sun hour were obtained from Ethiopia national meteorological agency.
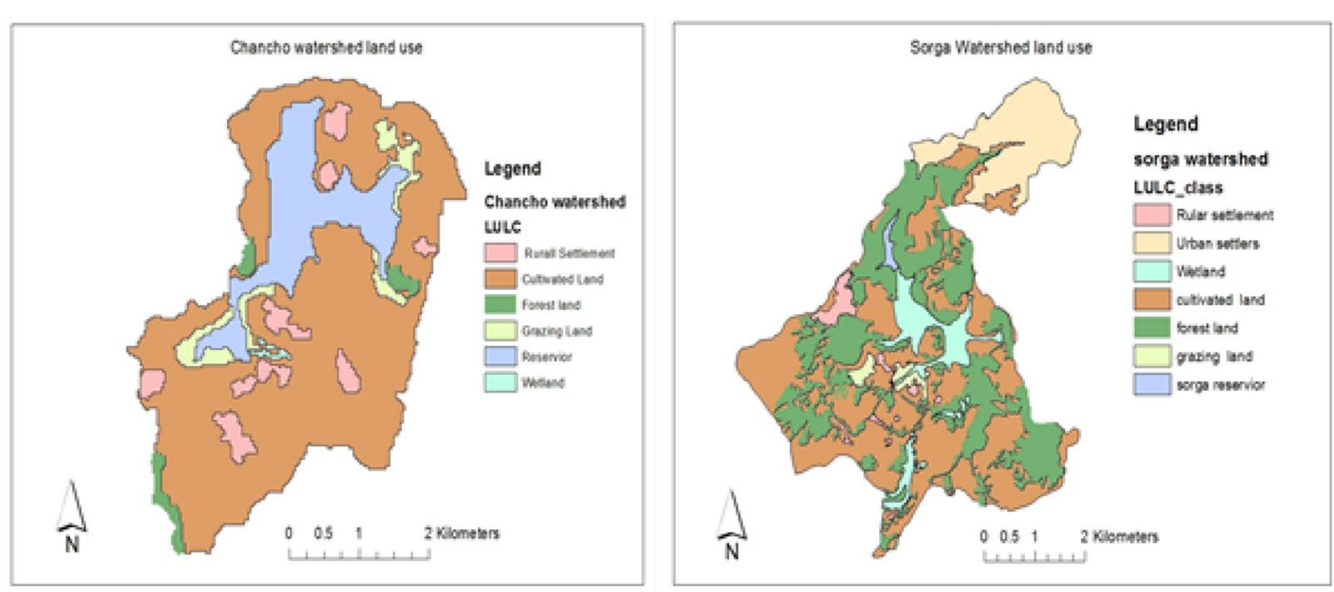

Fig. 2 Land use/cover map 

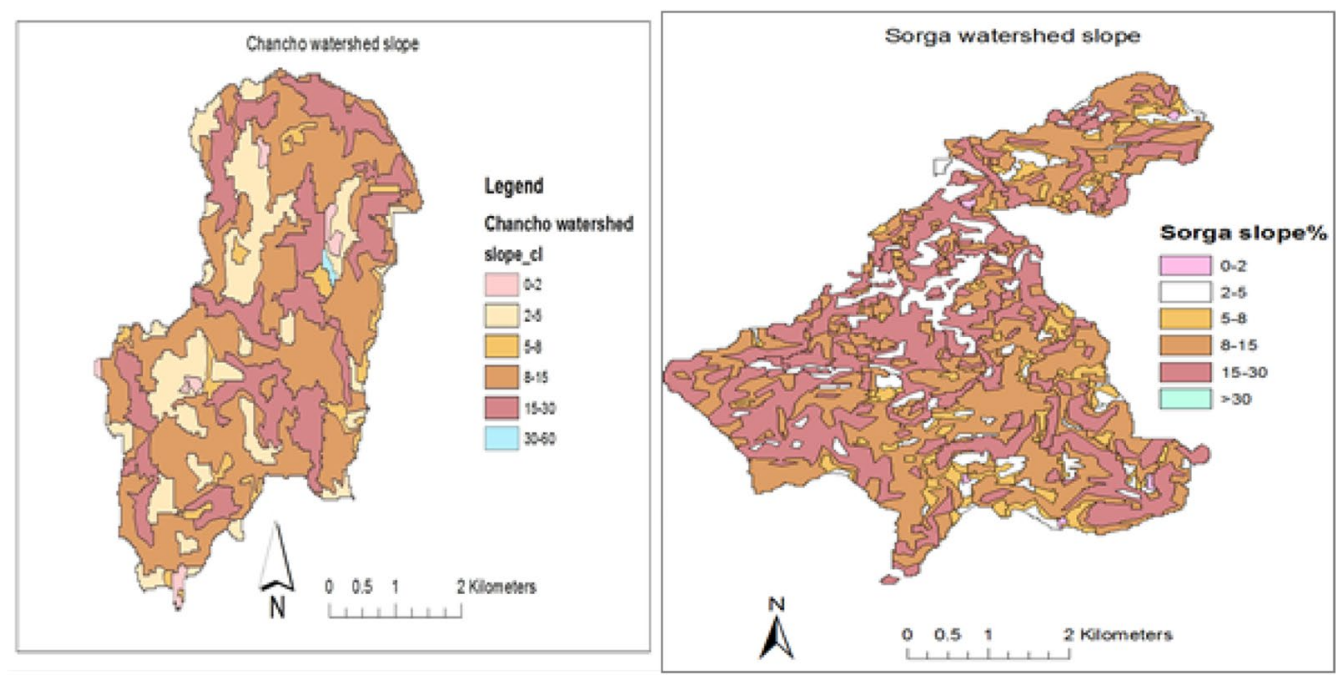

Fig. 3 Slope map

Table 1 Slope gradient share of each land use/cover types in hectare

\begin{tabular}{|c|c|c|c|c|c|c|c|}
\hline \multirow[t]{2}{*}{ Slope class } & \multicolumn{4}{|c|}{ Sorga sub watershed/ha } & \multicolumn{3}{|c|}{ Chancho sub watershed/ha } \\
\hline & Cultivated & Forest & Urban & Grass & Cultivated & Grass & Residential \\
\hline $0-5 \%$ & 218.28 & 47.12 & 21.60 & - & 202.92 & 25.96 & 10.35 \\
\hline $5-6 \%$ & 288.31 & 51.59 & 43.49 & - & 244.80 & 21.95 & 12.52 \\
\hline $8-15 \%$ & 835.50 & 267.57 & 106.67 & 3.26 & 622.67 & 84.21 & 26.22 \\
\hline $15-30 \%$ & 687.19 & 347.46 & 101.23 & 11.97 & 452.77 & 50.27 & 12.85 \\
\hline$>30 \%$ & 91.24 & 63.86 & - & 4.83 & 34.60 & 1.58 & - \\
\hline
\end{tabular}

The stations are found in Sorga sub watershed, bordering Chancho sub watershed and Nekemte city. The area receives maximum amount of rainfall during the year 2014 was $2520 \mathrm{~mm}$ and the minimum recorded rain fall was 1524 for the year 1989. Then, the mean annual rainfall of the study areas were $2022 \mathrm{~mm}$ and annual average temperature was $19.85^{\circ} \mathrm{C}$. The year in the area is divided into two seasons: a rainy season which occurs from May to October and a dry season from November to April.

\section{Methods}

\section{Arc SWAT model setup} Watershed delineation

Arc SWAT uses Digital Elevation Model (DEM) and automatically delineate the watershed into several hydrological connected sub-basin. The watershed delineation operation uses ArcGIS and spatial analyst extension functions to perform watershed delineation. The first step in the watershed delineation was loading the properly projected DEM. To reduce the processing time of the GIS functions, a mask was created over the DEM around the study area. Next, a polyline stream network dataset was burnt-into force SWAT sub-basin reaches to follow known stream reaches. Burning-in a stream network improves hydrological segmentation, and sub-watershed delineation. After the DEM grid was loaded and the stream networks superimposed, the DEM map grid was processed to remove the non-draining zones.

The initial stream network and sub-basin outlets were defined based on drainage area threshold approach. The threshold area defines the minimum drainage area required to form the origin of a stream. The interface lists a minimum, maximum and suggested threshold area.

\section{Hydrologic response unit analysis}

Hydrologic response units (HRUs) are lumped land areas within the sub-basin that are comprised of unique land cover, soil, slope and management combinations. HRUs enable the model to reflect differences in evapotranspiration and other hydrologic conditions for different land use/covers and soils.

Land use/cover and soil data in a projected grid file format were loaded into the Arc SWAT interface to determine the area and hydrologic parameters of each 

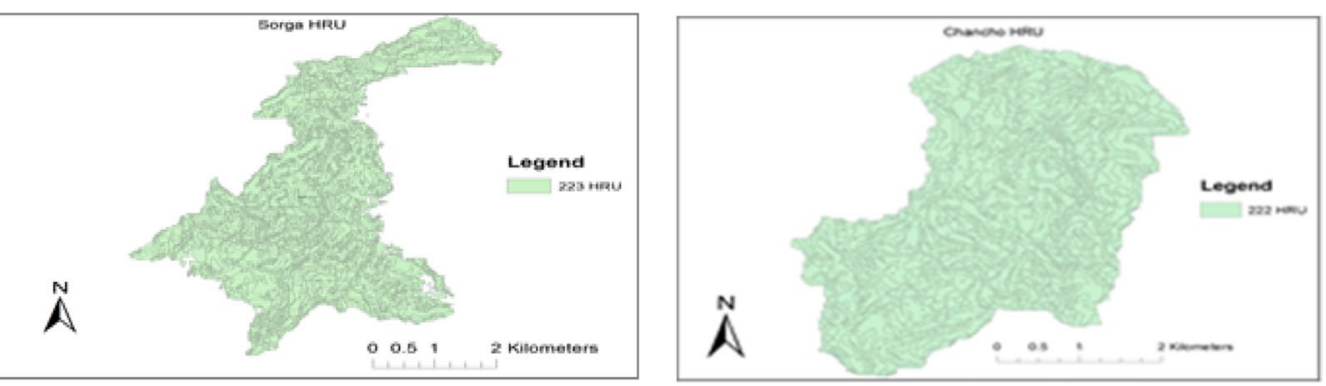

Fig. 4 Map of hydrological response units

land-soil category simulated within the sub-watershed. Land use/cover types were defined using the look up table. A look-up table that identifies the 4-letter SWAT code for the different categories of land cover/land use was prepared so as to relate the grid values to SWAT land use/cover type. After the land use SWAT code assigned to all map categories, calculation of the area covered by each land use and reclassification was done. Soil layer in the map was also linked to the user soil database information by loading the soil look-up table and reclassification applied. Then, land use, soil and slope classes were integrated to define the hydrologic response units. In order to minimize the number of HRUS, $25 \%$ for land use/ cover, $15 \%$ for slope and $10 \%$ for soil thresholds percentage were assigned. The DEM data used during the watershed delineation was also used for slope classification. Based on the suggested minimum and maximum ranges, six slope classes $(0-5,5-8,8-15,15-30$ and $>30 \%)$ were applied and slope grids reclassified. Then, land use, soil and slope grids were overlaid in order to produce HRUS based on threshold percentage assigned for each of them (Fig. 4).

\section{Importing climate data}

The climatic variables required by SWAT daily precipitation, maximum and minimum temperature, solar radiation, wind speed and relative humidity were prepared in the appropriate dbase format. Due to data availability and quality, daily precipitation, and maximum and minimum temperature in dbase format were the climatic input variables imported together with their weather location. And due to lack of complete weather data we used the Hargreaves method which uses temperature to determine the potential evapotranspiration.

\section{Sensitivity analysis}

The sensitivity analysis of this study was done using onefactory-at-a time and global sensitivity analysis methods. The inputs were the observed daily flow data and monthly sediment yield. The sensitive parameters to flow and sediment yield evaluated by $\mathrm{t}$-stat and $\mathrm{p}$-value and ranked accordingly.

\section{Model calibration and validation}

Two sub watersheds are selected for this study in which Chancho Sub watershed flow and sediment data used for model calibration and Sorga sub watershed independent data used for model validation. Simulation of the predicted water quality parameters was undertaken in Sorga sub watershed.

Calibration and validation were carried out in SWATCUP 2012 version 5.1.4 using Sequential Uncertainty Fitting (SUFI-2) algorithm, based on the SWAT-CUP user manual (Abbaspour 2013). SUFI-2 is a semi-automated calibration and uncertainty analytical algorithm (Zhou et al. 2014) that accounts for all sources of uncertainty, including uncertainty in the driving variables (e.g. rainfall), conceptual model, parameters and measured data (Vilaysane et al. 2015). The model was calibrated and validated by using river flow and sediment data of the study sub watersheds. Sensitivity analysis was carried out to identify the most sensitive parameters for the model calibration using global sensitivity analysis which is an automatic sensitivity analysis tool implemented in SWAT.

In automated calibration, the list of selected parameters for optimization of object function is usually the momentum of difference of observed and computed values. For SWAT model calibration, there is a manual option in ARCSWAT, and a SWAT-CUP (SWAT Calibration and Uncertainty Programs) program with link to SWAT output for automated calibration is used. In SWAT-CUP, there are four methods for calibration, uncertainty and sensitivity analysis (Abbaspour et al. 2007). In this study, SUFI-2 optimization method was applied. In SUFI-2, the uncertainty parameter explains all sources of uncertainties. The degree, to which all uncertainties are explained, is expressed by parameter referred to as the P-factor, which is given as the percentage of measured data enveloped by the $95 \%$ estimation uncertainty (95PPU). The 95PPU is determined at the percentage of cumulative 
distribution between 2.5 and $97.5 \%$ of an output variable. Model Application A simple framework that is used for hydrologic modeling and calibration by SWAT and SWAT-CUP.

\section{Model evaluation}

The performance of SWAT was evaluated using statistical measures to determine the quality and reliability of predictions when compared to observed values. Coefficient of determination $\left(\mathrm{R}^{2}\right)$ and Nash-Sutcliffe simulation efficiency (ENS) were the goodness of fit measures used to evaluate model prediction. The $\mathrm{R}^{2}$ value is an indicator of strength of relationship between the observed and simulated values. The Nash-Sutcliffe simulation efficiency (ENS) indicates how well the plot of observed versus simulated value fits the 1:1 line. If the measured value is the same as all predictions, ENS is 1. If the Eis between 0 and 1 , it indicates deviations between measured and predicted values. If ENS is negative, predictions are very poor, and the average value of output is a better estimate than the model prediction (Nash and Sutcliffe 1970).

\section{Data analysis}

A simulated mean value of each parameter was calculated by using Excel. Spearman's rank correlation analyses were used to explore the relationships between land use/cover types and simulated water quality variables in both watersheds. Analysis of variance on the mean values of all water quality variables were also performed to test if there were any significant differences between land use categories.

\section{Result and discussion}

\section{Sensitive parameters}

Sensitive parameter analysis was carried out in order to identify the most sensitive parameters determining the model output. The parameter that had the most influence on the flow and sediment load was identified. Global sensitivity analysis uses t-test and p-values to determine the sensitivity of each parameter. The $\mathrm{t}$-stat provides a measure of the sensitivity. The larger in absolute values indicates more sensitivity. The $\mathrm{p}$-values determine the significance of the sensitivity. A p-value close to zero has more significance (Singh et al. 2014). This sensitivity was performed after an iteration process. Therefore, global sensitivity analysis was used to identify the most sensitive parameters. Accordingly, channel effective hydraulic conductivity $(\mathrm{mm} / \mathrm{h})\left(\mathrm{V} \_\mathrm{CH} \_\mathrm{K} 2 . \mathrm{rte}\right)$ was found to be the most sensitive parameter, followed by Base flow alpha factor (days) (V_ALPHA_BNK.rte) to flow. Ground water flow Alpha factor (V-ALPHA-BF.gw) is the most sensitive parameters to sediment load followed by Threshold depth of water in the shallow aquifer required for return flow to occur (V_GWQMN.gw) (Table 2).

\section{Calibration of the SWAT parameters}

Independently recorded flow data and sediment yield from both sub watersheds were used for calibration and validation of the model. Data from Chancho sub watershed was used for model calibration and Sorga for validation (Fig. 5).

\section{Model calibration}

Calibration was performed by using for 20 years flow data (January 1994 to December 2013) including 3 years warm up periods in Chancho sub-watershed. The simulated daily flow results were compared with the observed daily discharge recorded from river flow monitoring station (Fig. 5). It was found that by using the default parameters, the simulated flow was very close to the actual monitored flow rate (Fig. 6), The SWAT model parameters were calibrated until there was a satisfactory agreement between the simulated flow rate and the observed monitored flow

Table 2 Summary of global sensitivity analysis

\begin{tabular}{|c|c|c|c|c|c|}
\hline Variables & Parameter name & Description & t-Stat & p-value & Rank \\
\hline \multirow[t]{6}{*}{ Flow } & 3:R_SOL_BD(..).sol & Soil bulk density & -0.06 & 0.95 & 6 \\
\hline & $2: V \_G W \_D E L A Y . g W$ & Groundwater delay time (days) & 0.45 & 0.65 & 4 \\
\hline & $1: \mathrm{R} \_$CN2.mgt & SCS runoff curve number $(C n 2)$ & 0.51 & 0.61 & 3 \\
\hline & $6: V_{\text {_ESCO.hru }}$ & Soil evaporation compensation factor & -0.91 & 0.36 & 5 \\
\hline & $4: V \_$ALPHA_BNK.rte & Base flow alpha factor (days) & 1.17 & 0.24 & 2 \\
\hline & $5: V_{2}$ C CH_K2.rte & Channel effective hydraulic conductivity (mm/h) & 1.58 & 0.12 & 1 \\
\hline \multirow[t]{4}{*}{ Sediment } & 3.V_GW_DELAY.gW & $\begin{array}{l}\text { Threshold depth of water in the shallow aquifer required } \\
\text { for return flow to occur }\end{array}$ & -0.15 & 0.89 & 3 \\
\hline & 4.V_GWQMN.gw & Ground water alpha factor & 0.39 & 0.72 & 2 \\
\hline & 2.V_ALPHA-BF.gw & & 0.45 & 0.69 & 1 \\
\hline & 1.R_CN2.mgt & & -0.85 & 0.44 & 4 \\
\hline
\end{tabular}




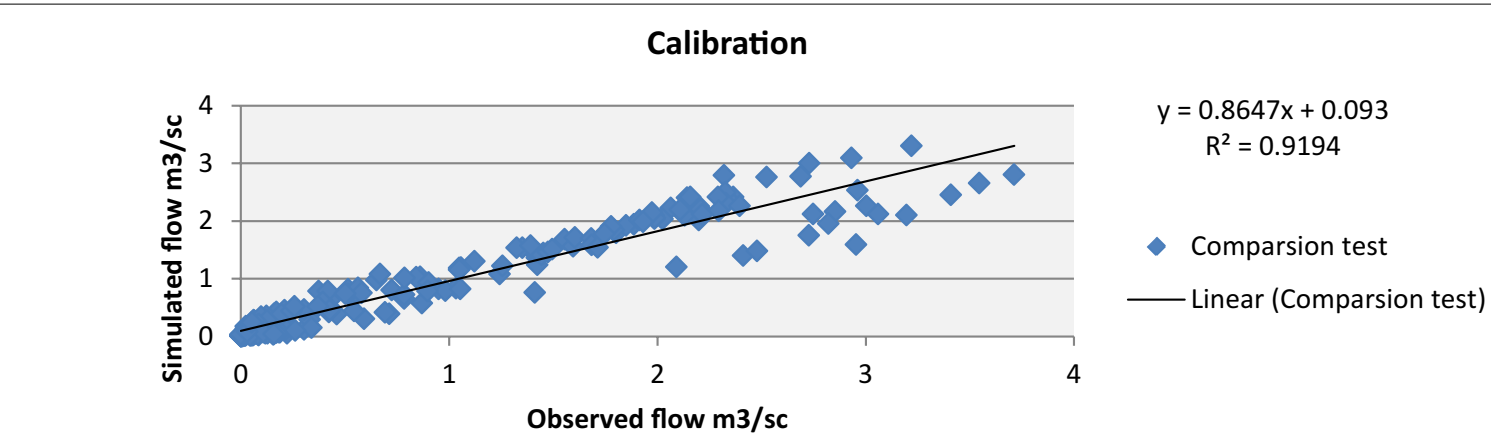

Fig. 5 Observed verse simulated to flow during calibration

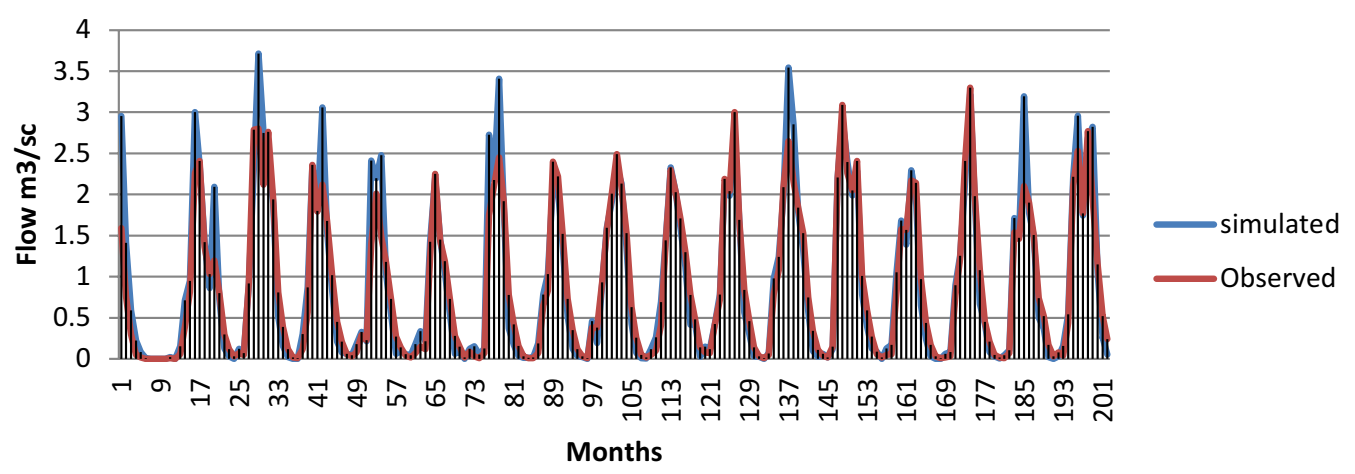

Fig. 6 Observed and simulated flow rate during calibration

Table 3 Evaluation of the accuracy of the SWAT model

\begin{tabular}{lllll}
\hline Variables & Periods & Coefficient of determination $\left(\mathbf{R}^{\mathbf{2}}\right)$ & Nash-Sutcliffe coefficients (ENS) & $\begin{array}{l}\text { Relative } \\
\text { errors (RE) }\end{array}$ \\
\hline River flow & & 0.91 & 0.96 & 0.5 \\
& Calibration & 0.83 & 0.74 & 0.21 \\
Sediment flow & Validation & 0.88 & 0.89 & 0.3 \\
& Calibration & 0.81 & 0.68 & 0.211 \\
\hline
\end{tabular}

data., the simulated flow was close to the monitored flow rate (Table 3), is also a good agreement between them.

Simulated monthly sediment yield results also compared with the observed monthly sediment yield and we found that the simulated one was close to actual sediment load and the calibration result indicate a satisfactory agreement between them (Fig. 7).

\section{Model validation}

Validation of the model for flow was done for an independent data obtained form Sorga sub watershed for 20 years from 1997 to 2013 and sediment flow for one year 2013. The validation result indicates both flow rate and sediment yield gives a satisfactory result for the prediction of water quality variables (Figs. 8, 9, 10).

\section{Model evaluation}

Model calibration result was found that the model has strong predictive capability with $\mathrm{R}^{2}=0.91, \mathrm{NS}=0.96$ and $\mathrm{RE}=0.5$ for Chancho sub watershed and model validation is also very good predictive capacity of the model for river flow rate with value of 0.83 and 0.74 for $R^{2}$ and ENS, respectively. High value of $\mathrm{R}^{2}$ and ENS for monthly flow rate and sediment yield both for calibration and validation period indicate the predictive capacity of the model and it is appropriate to estimate the water quality of the study sub watershed (Table 3 ). 


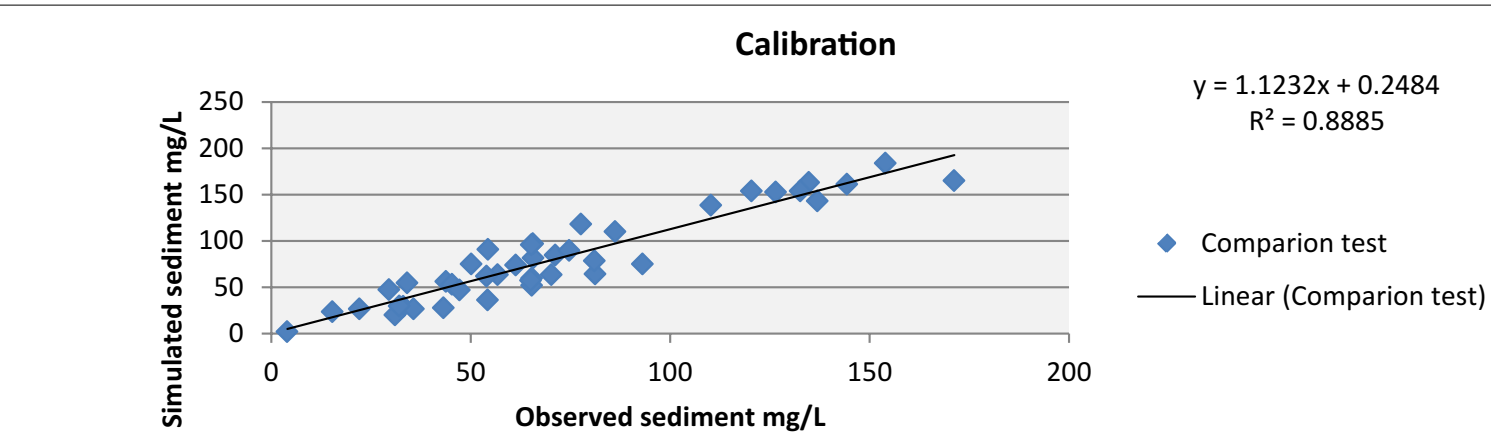

Fig. 7 Observed verse simulated to sediment during calibration

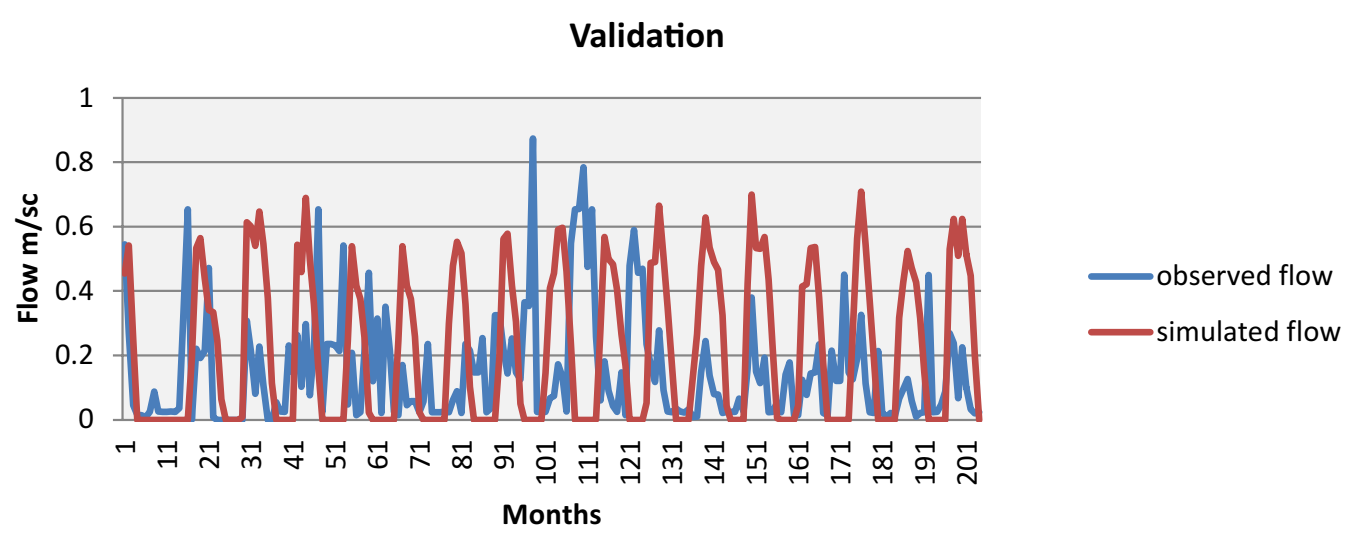

Fig. 8 Observed and simulated flow rate during validation

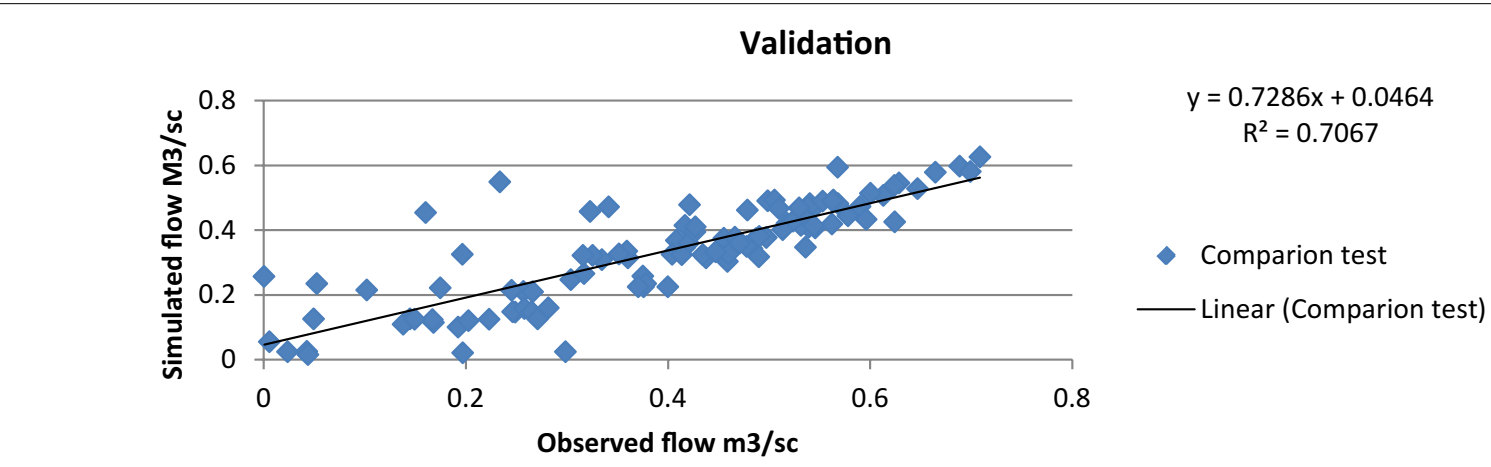

Fig. 9 Observed verse simulated to flow during validation

Interaction effects of land use/cover types and slope gradient in sediment and nutrient loss

The model output indicated (Table 4) that the interaction of urban land with slope gradient (15-30\%) produced higher values of sediment loss (461 t/h/year), followed by the interaction of cultivated and forestland with slope gradient (15-30\%), which resulted in higher mean value
(383 and $342 \mathrm{t} / \mathrm{h} /$ year) than the other combinations. The minimum mean value was recorded under the interaction of grassland and slope gradient at $15-30 \%$ and $5-8 \%$ (190 and 15 t/h/year), respectively.

Organic nitrogen transported from each HRU of different land use/cover types and slope gradient showed a varied result as the slope increased under all land use/ 
Validation

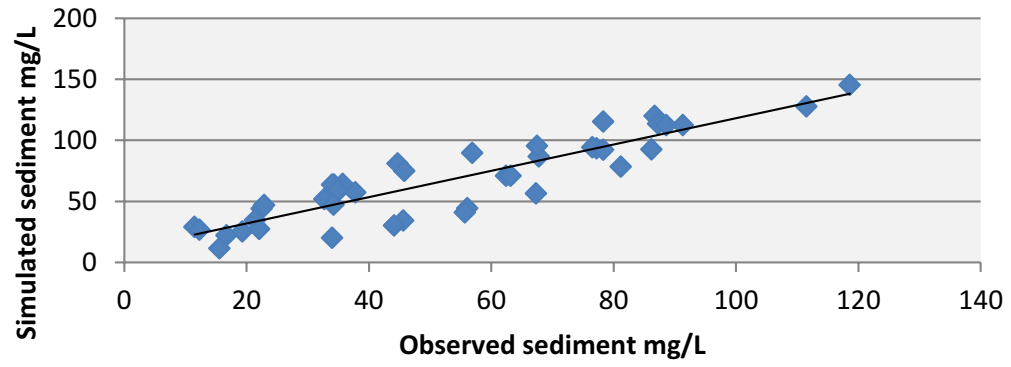

$$
\begin{gathered}
y=1.0785 x+10.348 \\
R^{2}=0.8097
\end{gathered}
$$

Observed

- Linear (Observed)

Observed sediment $\mathrm{mg} / \mathrm{L}$

Fig. 10 Observed verse simulated to sediment flow during validation

\begin{tabular}{|c|c|c|c|c|c|c|c|c|c|}
\hline \multirow[t]{2}{*}{ LULC } & \multirow[t]{2}{*}{ Slope class } & \multicolumn{8}{|c|}{ Losses of sediment and nutrient from different slope gradient } \\
\hline & & SYLDt/ha & ORGNkg/ha & ORGPhg/ha & NSURQkg/ha & SOLPkg/ha & SEDPkg/ha & LATQNO3kg/ha & GWNO3kg/ha \\
\hline \multirow[t]{5}{*}{ Cultivated } & $0-5 \%$ & $316^{\mathrm{a}}$ & $38.935^{\mathrm{a}}$ & $5.904^{\mathrm{a}}$ & $3.114^{\mathrm{a}}$ & $0.139^{\mathrm{a}}$ & $4.991^{\mathrm{a}}$ & $0.713^{\mathrm{a}}$ & $11.944^{\mathrm{a}}$ \\
\hline & $5-8 \%$ & $373^{\mathrm{a}}$ & $37.934^{\mathrm{a}}$ & $5.965^{\mathrm{a}}$ & $2.876^{\mathrm{a}}$ & $0.122^{\mathrm{a}}$ & $5.017^{\mathrm{a}}$ & $0.776^{\mathrm{a}}$ & $12.409^{\mathrm{a}}$ \\
\hline & $8-15 \%$ & $347^{\mathrm{a}}$ & $38.562^{\mathrm{a}}$ & $6.078^{\mathrm{a}}$ & $3.779^{a}$ & $0.160^{\mathrm{a}}$ & $4.792^{\mathrm{a}}$ & $0.660^{\mathrm{a}}$ & $10.990^{\mathrm{a}}$ \\
\hline & $15-30 \%$ & $383^{a}$ & $40.031^{a}$ & $6.097^{a}$ & $5.660^{\mathrm{a}}$ & $0.136^{a}$ & $5.441^{\mathrm{a}}$ & $0.731^{a}$ & $12.017^{\mathrm{a}}$ \\
\hline & $>30 \%$ & $269^{b}$ & $36.948^{\mathrm{a}}$ & $6.396^{\mathrm{a}}$ & $5.612^{\mathrm{a}}$ & $0.162^{\mathrm{a}}$ & $4.189^{\mathrm{a}}$ & $0.941^{\mathrm{a}}$ & $9.790^{\mathrm{a}}$ \\
\hline \multirow[t]{5}{*}{ Forest } & $0-5 \%$ & $202^{\mathrm{a}}$ & $37.240^{\mathrm{a}}$ & $5.466^{\mathrm{a}}$ & $2.470^{\mathrm{a}}$ & $0.155^{\mathrm{a}}$ & $5.352^{\mathrm{a}}$ & $0.727^{a}$ & $10.609^{a}$ \\
\hline & $5-8 \%$ & $216^{a}$ & $42.271^{a}$ & $6.486^{\mathrm{a}}$ & $3.029^{a}$ & $0.165^{\mathrm{a}}$ & $5.501^{\mathrm{a}}$ & $0.964^{\mathrm{a}}$ & $11.254^{\mathrm{a}}$ \\
\hline & $8-15 \%$ & $259^{a}$ & $34.872^{\mathrm{a}}$ & $6.055^{\mathrm{a}}$ & $3.734^{\mathrm{a}}$ & $0.198^{\mathrm{a}}$ & $5.201^{\mathrm{a}}$ & $0.837^{a}$ & $11.427^{\mathrm{a}}$ \\
\hline & $15-30 \%$ & $342^{\mathrm{a}}$ & $34.125^{\mathrm{a}}$ & $5.827^{\mathrm{a}}$ & $3.596^{\mathrm{a}}$ & $0.179^{a}$ & $5.006^{\mathrm{a}}$ & $0.875^{a}$ & $11.847^{\mathrm{a}}$ \\
\hline & $>30 \%$ & $328^{\mathrm{a}}$ & $31.759^{a}$ & $7.141^{\mathrm{a}}$ & $4.336^{\mathrm{a}}$ & $0.192^{\mathrm{a}}$ & $4.556^{\mathrm{a}}$ & $0.696^{\mathrm{a}}$ & $10.020^{a}$ \\
\hline \multirow[t]{4}{*}{ Urban } & $0-5 \%$ & $309^{a}$ & $79.180^{b}$ & $9.861^{\mathrm{a}}$ & $1.957^{\mathrm{a}}$ & $0.088^{\mathrm{a}}$ & $11.310^{\mathrm{b}}$ & $0.711^{\mathrm{a}}$ & $12.366^{\mathrm{a}}$ \\
\hline & $5-8 \%$ & $374^{\mathrm{a}}$ & $72.594^{\mathrm{a}}$ & $10.158^{a}$ & $2.650^{\mathrm{a}}$ & $0.157^{a}$ & $10.704^{\mathrm{a}}$ & $1.005^{\mathrm{a}}$ & $12.742^{\mathrm{a}}$ \\
\hline & $8-15 \%$ & $431^{\mathrm{a}}$ & $73.250^{\mathrm{a}}$ & $10.588^{a}$ & $3.237^{\mathrm{a}}$ & $0.200^{\mathrm{a}}$ & $10.071^{\mathrm{a}}$ & $0.716^{\mathrm{a}}$ & $12.396^{\mathrm{a}}$ \\
\hline & $15-30 \%$ & $461^{\mathrm{a}}$ & $70.371^{a}$ & $10.084^{\mathrm{a}}$ & $2.769^{a}$ & $0.167^{a}$ & $9.846^{\mathrm{a}}$ & $0.697^{a}$ & $11.355^{\mathrm{a}}$ \\
\hline \multirow[t]{5}{*}{ Grass } & $0-5 \%$ & $236^{\mathrm{a}}$ & $38.136^{a}$ & $5.618^{\mathrm{a}}$ & $2.966^{\mathrm{a}}$ & $0.122^{\mathrm{a}}$ & $5.828^{\mathrm{a}}$ & $0.523^{\mathrm{a}}$ & $13.115^{\mathrm{a}}$ \\
\hline & $5-8 \%$ & $15^{b}$ & $41.868^{\mathrm{a}}$ & $7.018^{\mathrm{a}}$ & $3.812^{\mathrm{a}}$ & $0.171^{\mathrm{a}}$ & $4.600^{\mathrm{a}}$ & $0.557^{a}$ & $12.135^{\mathrm{a}}$ \\
\hline & $8-15 \%$ & $35^{b}$ & $39.160^{\mathrm{a}}$ & $6.577^{\mathrm{a}}$ & $2.946^{\mathrm{a}}$ & $0.173^{\mathrm{a}}$ & $6.592^{\mathrm{a}}$ & $0.438^{\mathrm{a}}$ & $11.184^{\mathrm{a}}$ \\
\hline & $15-30 \%$ & $193^{\mathrm{a}}$ & $40.359^{a}$ & $6.165^{\mathrm{a}}$ & $3.241^{\mathrm{a}}$ & $0.161^{a}$ & $4.564^{\mathrm{a}}$ & $0.522^{\mathrm{a}}$ & $11.758^{\mathrm{a}}$ \\
\hline & $>30 \%$ & $45^{b}$ & $41.755^{a}$ & $7.733^{\mathrm{a}}$ & $5.287^{\mathrm{a}}$ & $0.175^{\mathrm{a}}$ & $2.673^{\mathrm{a}}$ & $0.5^{\mathrm{a}}$ & $10.556^{\mathrm{a}}$ \\
\hline
\end{tabular}

Table 4 Simulated mean values of sediment and nutrient loss from the combination of LILC and slope gradient

SYLDt_ha = sediment loss ton/hectare, ORGNkg_ha = organic nitrogen kilogram/hectares, ORGPhg_ha = organic phosphors gram/hectare, NSURQkg_ha = nitrate in surface runoff kilogram/hectares, SOLPkg_ha = soluble phosphors kilogram/hectares, SEDPkg_ha = sediment phosphorus kilogram/hectares, LAT_Q_NO3kg_ ha $=$ nitrate in lateral flow kilogram/hectares, GWNO3kg_ha = nitrate in ground water kilogram/hectares

Different superscript letters in column indicate significant difference at $a=0.05$

cover types. The interaction of urban land with all slope range produced a higher ORGN $\mathrm{kg} / \mathrm{ha}$ than other land use/cover types. The maximum mean value of ORGN was recorded from the interaction of urban land with $8-15 \%$ slope $(73 \mathrm{~kg} / \mathrm{ha} /$ year $)$ and had significant difference at $(p<0.05)$ than other lands of the same slope gradient, that is, cultivated land $(47 \mathrm{~kg} / \mathrm{ha})$, forestland (34 kg/ha), and grassland (39 kg/ha). The least mean value of ORGN (32.9 kg/ha) was recorded from cultivated land at the slope gradient of $0-5 \%$ (Table 4).

The amount of phosphorus stored in the stable organic phosphorus and transported from each HRU of land use/ cover types varied at different slope gradient. Each land use/cover type produced different ORGP within and between slope ranges. The highest simulated mean value was recorded from urban land of (10.5 g/ha/year) at the 
slope class (8-15\%), as compared to the other combined followed by grassland land, which produced a mean of $7.7 \mathrm{~g} / \mathrm{ha} /$ year of ORGP at the slope gradient $>30 \%$.The minimum ORGP transported was observed under cultivated land (5.05 g/ha/year) at 0-5\% slope. Urban land transported higher ORGP than other land types at all slope classes and had no significant difference at $(\mathrm{p}<0.05)$ between them (Table 4).

The simulated mean value of nitrate transported with surface runoff varies depending on the interaction of land use/cover type with slope gradient. Cultivated land at $15-30 \%$ slope produced more nitrate in surface water than other combinations $(5.6 \mathrm{~kg} / \mathrm{h} /$ year $)$. Grassland also produced a higher mean value of NSURQ $(5.3 \mathrm{~kg} / \mathrm{ha})$ at $>30 \%$ slope gradient next to cultivated. The minimum value of NSURQ was recorded from urban land at slope range of $8-15 \%$ with value of $(1.59 \mathrm{~kg} / \mathrm{ha})$ (Table 4$)$.

The mean values of mineral phosphorus absorbed to sediments and transported from each HRUs of land use/cover and slope gradient were high at $8-15 \%$ slope range for all land use/cover types. The higher mean value was produced from urban land at slope range of 5-8\% $(11.3 \mathrm{~kg} / \mathrm{ha})$ than the other interactions, followed by forestland at the same slope produced SEDP ( $5.8 \mathrm{~kg} / \mathrm{ha})$. The minimum mean value was recorded from grassland at slope range $>30 \%(2.67 \mathrm{~kg} / \mathrm{ha})$.

The simulated mean values of NO3 transported with the ground water loading from the HRU vary based on the nature of land use/cover and slope gradient. The higher mean value of GWNO3 was recorded from cultivated land at slope of $30 \%$ than other interaction within and between land use/cover types. Grassland at slope $0-5 \%$ produced more GWNO3 $(11 \mathrm{~kg} / \mathrm{ha})$ next to cultivated land and forestland, which produced less or minimum mean value under all interactions as compared to others (Table 4).

Simulated mean value of sediment and nutrient transported from the interaction of different land use/cover types and slope gradient showed different values between land use/cover types. Each land use/cover type was produced different sediment and nutrient losses under a similar slope gradient. Therefore, the combined effect of land use/cover types and slope gradient analyzed and evaluated for each land use/cover types separately (Table 4).

The model output indicated that the interaction of cultivated land with slope gradient $(15-30 \%)$ produced the higher values of sediment. AS slope gradient increases up to $30 \%$ slope of cultivated land, the value of sediment increased then after declined The interaction of forestland and slope gradient at (15-30\%) slope produced higher value of sediment but statistically had no significant difference. This result indicated that as slope gradient increased from $0-5 \%$ to $15-30 \%$ sediment values also increased then after declined (Fig. 11). Combination of urban land and slope gradient at (15-30\%) produced higher value of sediment with no significant difference among the mean values. This result indicated that as slope gradient increased from $0-5 \%$ to $15-30 \%$ sediment values also increased limitlessly. Grassland and slope gradient at (15-30\%) produced higher mean value of sediment than the others combination, and had a significant difference $(\mathrm{p}<0.05)$. The mean value of sediment increased as slope increases from 5 to $15 \%$ slope then after declined (Fig. 11).

The higher mean values of ORGN recorded at slope gradient $15-30 \%$ in cultivated land. As slope gradient increased the values of both nutrients were increased until it reaches 30\% slope similarly, and then declined with no significant difference between them (Fig. 12).

Nitrate in later flow $\left(\mathrm{LAQTNO}_{3}\right)$ in combination of forest land slope gradient showed that the higher mean values of those variables were recorded at $5-8 \%$ slope gradient. As slope gradient of forestland increased beyond this range the values of $\mathrm{LATNO}_{3}$ were declined (Fig. 13) this indicates that high and dense forest is located at the steeper land in the study area.

The simulated mean values of $\mathrm{NO}_{3}$ transported into main channel into the lateral loading from the HRU was

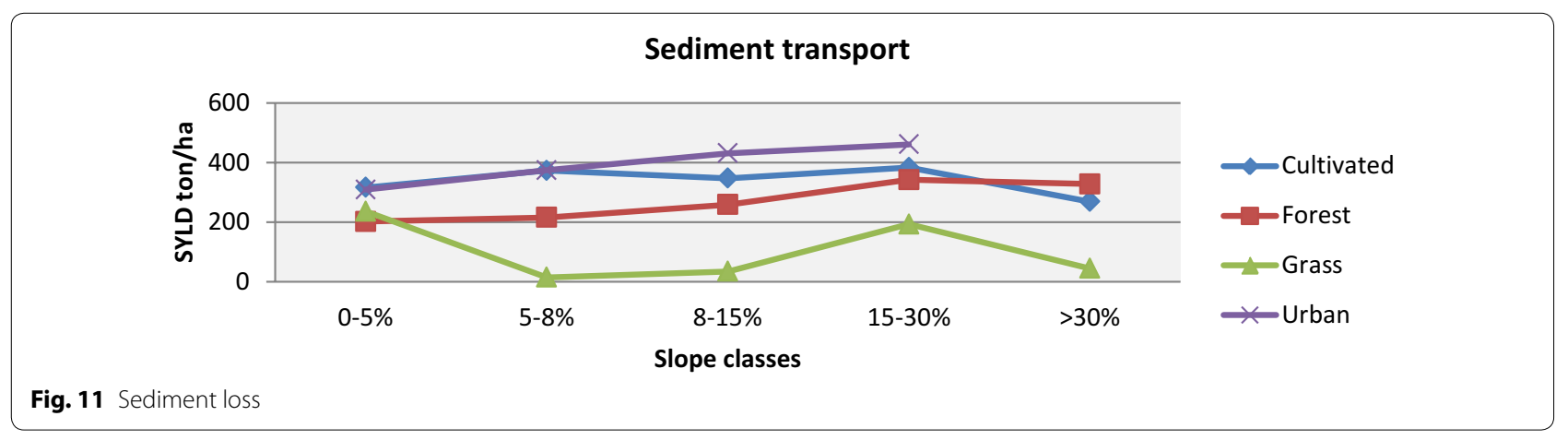


varied based on the combination of cultivated land and slope gradient. Nitrate transport in the lateral flow is decreased as slope gradient increased beyond $>30 \%$ in cultivated land. The simulated mean value of $\mathrm{NO}_{3}$ transported in lateral flow of forestland under different slope gradient was almost showed a similar trend with no significant difference among them (Fig. 13).

The simulated mean values of sediment phosphors (ORGPh), nitrate in surface runoff (NSURQ), were showed a similar trends in responding to changed slope gradient in cultivated land. As slope gradient increased the values of those variables were also increased with no any significant difference among their mean values (Figs. 14, 15).

\section{Correlation between sediment, nutrient transport} and slope gradient of different land use/cover types

Correlation analyses were undertaken between water quality variables, and slope gradient in order to understand the effect of slope on each variable and the relation between variables. The relationships between slope and water quality variables and among water quality variables vary depending up on land use/cover type.
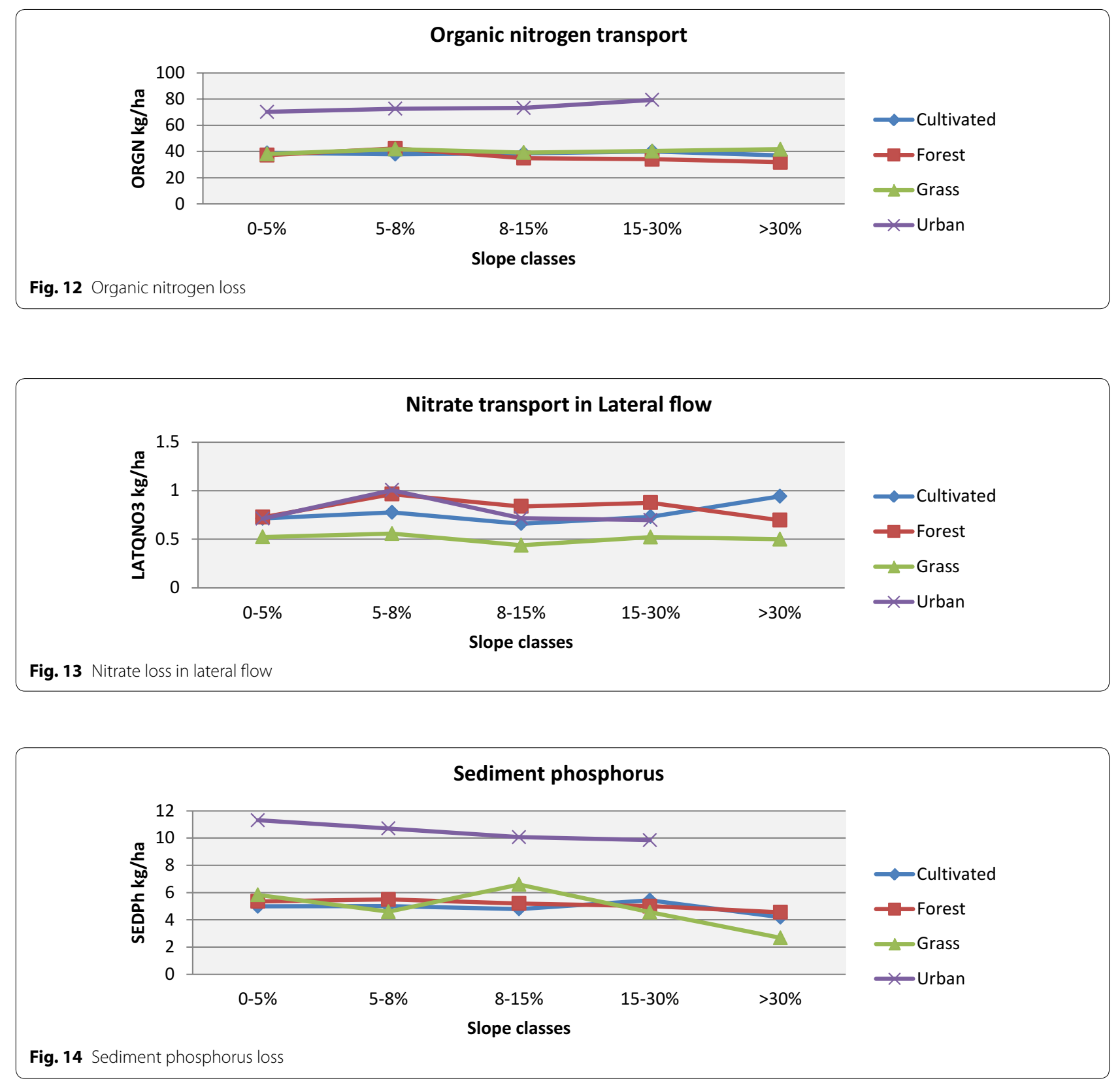


\section{Nitrate transport in surface runoff}

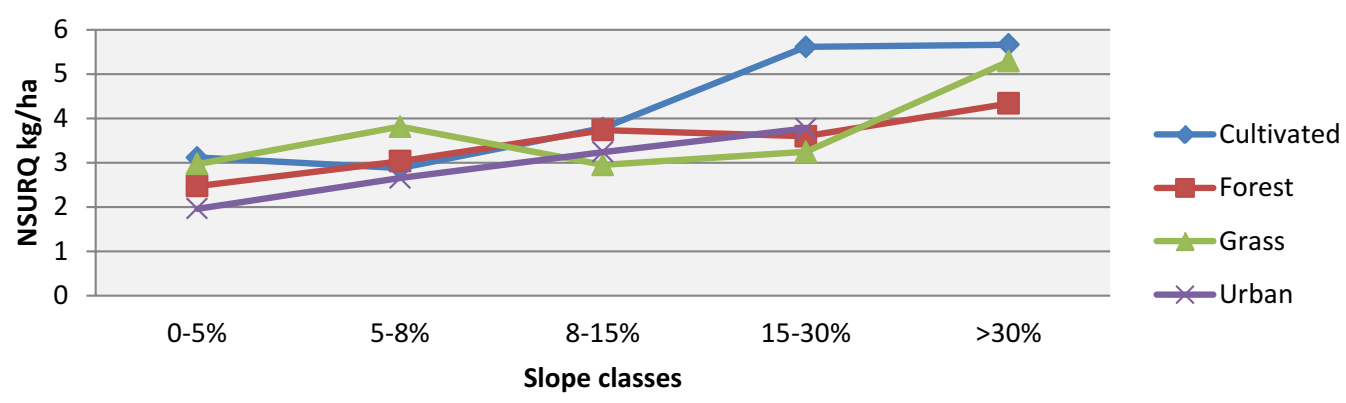

Fig. 15 Nitrate loss in surface runoff

Therefore, Spearman's rank correlation analysis indicates that the correlation between slope and sediment transport from HRU had a slight positive correlation $(r=0.106)$, which means that, as the mean slope increases, the mean of sediment transport showed a slight increase.

The correlation between slope gradient and organic nitrogen, organic phosphorus, sediment phosphorus and nitrate in lateral were showed a slight positive relationship between them, as slope gradient increased, the value of those water quality parameters are also increased whereas, soluble phosphorus transport and nitrate in ground water showed a negative relationship with slope gradient (Table 5).

The correlation among water quality variables showed different relationship depending on their respective land use/cover types. Sediment phosphors and organic nitrogen, organic $\mathrm{N}$ and $\mathrm{P}$, soluble $\mathrm{P}$ and nitrate in surface flow, ground water nitrate and nitrate in lateral flow had a strong positive correlation with each other, while sediment yield and soluble $\mathrm{P}$ had a strong negative correlation and the others variables had a slight positive and negative relationship with each other (Table 5).

\section{Discussion}

The SWAT model has been calibrated and validated before simulating the water quality variables. The model application gave satisfactory goodness of fits levels. The uneven contribution of mean values of sediment and nutrient transport from HRU of different land use/cover types and slope gradient is due to the dominant area coverage of land use/cover types and its interaction with their respective slope gradient.

The simulated mean value of sediment transport was higher at slope gradient class of $15-30 \%$ under all land use/cover types than other combined in the study sub watershed. Urban land produced higher mean values of sediment at $15-30 \%$ slope followed by cultivated land, this higher values of sediment is resulted from impervious and paved nature of urban land and continuous and steep slope cultivation of farmland. The mean values of organic $\mathrm{N}$ and $\mathrm{P}$ and sediment phosphorus are also higher in urban land with increasing trend as slope increased; this is due to the disposal of solid and liquid waste and influent to the environment by urban settlers. In general, the interaction of all land use/cover type and slope gradient indicated that, as slope gradient increased on average to $15-30 \%$, sediment and nutrient transport/

Table 5 Spearman's rank correlation between water quality variables of cultivated land

\begin{tabular}{|c|c|c|c|c|c|c|c|c|c|}
\hline & Slope & syldtha & orgnkgha & orgphgha & nsurqkgha & solpkgha & sedpkgha & latqno3kgha & gwno3kgha \\
\hline Slope & 1.0000 & & & & & & & & \\
\hline syldtha & 0.1063 & 1.0000 & & & & & & & \\
\hline orgnkgha & 0.1006 & $0.3162^{*}$ & 1.0000 & & & & & & \\
\hline orgphgha & 0.1101 & 0.1145 & $0.8898^{*}$ & 1.0000 & & & & & \\
\hline nsurqkgha & -0.0429 & $-0.4296^{*}$ & $0.2095^{*}$ & $0.4701^{*}$ & 1.0000 & & & & \\
\hline solpkgha & -0.0089 & $-0.6274^{*}$ & 0.1512 & $0.4190^{*}$ & $0.8374^{*}$ & 1.0000 & & & \\
\hline sedpkgha & 0.1411 & $0.7325^{*}$ & $0.6590^{*}$ & $0.4890^{*}$ & $-0.3334^{*}$ & $-0.3315^{*}$ & 1.0000 & & \\
\hline latqno3kgha & 0.0468 & -0.1184 & $0.3826^{*}$ & $0.4112^{*}$ & $0.5175^{*}$ & $0.4352^{*}$ & -0.0336 & 1.0000 & \\
\hline gwno3kgha & -0.0349 & $0.1992^{*}$ & $0.4554^{*}$ & $0.2638^{*}$ & $0.1796^{*}$ & 0.0942 & $0.3071^{*}$ & $0.5824^{*}$ & 1.0000 \\
\hline
\end{tabular}

* indicates the parameters have stastically significant relationship at $\mathrm{p}=0.05$ 
loss increased and then decline beyond 30\%, except for nitrate in lateral and ground water flow. The simulated values of nitrate in lateral and ground water flow were decreased as slope of all land use/cover increased, due to the increase of surface runoff and reduced infiltration as slope increased. Therefore, the combined effects of urban land with its slope gradient contribute more sediment and nutrient transport limitlessly than others combined. And cultivated land contributes more sediment and nutrient loss at increased slope gradient than forest and grassland combined.

The correlation between water quality variables indicated that, all are correlated to each other differently. Sediment with organic N and P, sediment phosphors and nitrate in ground water were positively correlated, indicated that as sediment transport increase the value of those variables also increases, while it has a negative correlation with the other variables. Majority of the variables were positively correlated to each other. The result of correlation among water quality variables indicated that, more nutrients had a positive correlation with the slope gradient except nitrate in surface runoff, soluble $\mathrm{p}$ and ground water nitrate. The result of this study indicated that sediment and nutrient transported from the interaction of land use/cover types and slope gradient affect the watershed dynamics and hydrology significantly. Moreover, the existing land use/cover types and its slope gradient are the most important factor affecting watershed dynamism and hydrology in terms of sediment and nutrient transport from HRUs.

\section{Conclusion}

Using SWAT as analytical tool would help us to predict the plausible sediment and nutrient transport and its consequences on hydrology of the watersheds and it is a very comprehensive water quality analysis tool. The simulated values of water flow rate was very close to the actual monitored during calibration, the model can be used to characterize the current discharge a different water quality conditions in the different watershed under a similar climatic and geographic areas. The model predicted the future hydrological dynamisms caused under changing land use/cover types and direction of change and its management strategy to keep the health of the watersheds.

The cumulative effects of land use/cover types and slope gradient on watershed dynamics and hydrology was predicted based on the simulated values of sediment and nutrient transport from HRU in a watershed. The simulated mean values of sediment and nutrient transport showed that the interaction of land use and slope were produced different mean values but statistically had no significant different. Combined effects of cultivated land and slope gradient produced more sediment than other land use/cover types followed by urban land. In cultivated land as slope gradient increased values of sediment also increased until it reaches to $30 \%$ slope and then started to decline. In Forest and grassland sediment loss increased until $15 \%$ slope and then decline, but in urban land as slope gradient increases sediment and nutrient loss are also increased. Therefore, it was concluded that urban land and cultivated land with increased slope gradient under construction and cultivation, respectively, had more significant effect on watershed dynamics and hydrology in terms of loss of fertile top soil from upland, downstream water quality reduction and sedimentation of reservoir than others land use/cover in the study watershed. Therefore, avoiding utilizing steep slope land for construction and continuous cultivation and implementing integrated watershed management strategies are recommended to keep the natural dynamism of the watershed.

\section{Abbreviations}

ANOVA: analysis of variance; GIS: geographical information system; HRUs: hydrological response units; km: kilometer; LULCC: land use land cover change; mm: millimeter; SWAT: soil and water assessment tools; ha: hectare; m.a.s.l: meter above sea level; TP: total phosphorous.

\section{Acknowledgements}

The authors would like to Addis Ababa and Wollegga universities for their financial and Diga and Guto Gidda District for their cooperation in providing transport services during field work. We thank also Mr. Sanyi Regasa who is working in Oromia water work and design enterprise for his contribution in GIS work and soil data

\section{Authors' contributions}

TM has contributed in the acquisition of the data, data collection, data coding and entry, data analysis, interpretation of the result. DL and MA provided comment, suggestion and edited the manuscript. All authors read and approved the final manuscript.

\section{Funding}

This research was funded by Wollega University.

\section{Availability of data and materials}

The data used in this paper is with the authors and can be available upon demand.

Ethics approval and consent to participate Not applicable.

\section{Consent for publication}

Not applicable.

\section{Competing interests}

The authors declare that they have no competing interests.

\section{Author details}

${ }^{1}$ Center for Environmental Science, Addis Ababa University, Addis Ababa, Ethiopia. ${ }^{2}$ School of Earth Science, Addis Ababa University, Addis Ababa, Ethiopia. 
Received: 14 February 2019 Accepted: 3 June 2019

Published online: 22 June 2019

\section{References}

Abbaspour K (2013) SWAT-CUP (2012) SWAT calibration and uncertainty programs-a user manual, 103

Abbaspour KC, Yang J, Maximov I, Siber R, Bogner K, Mieleitner J, Zobrist J, Srinivasan R (2007) Modelling hydrology and water quality in the prealpine/alpine Thur watershed using SWAT. J Hydrol 333(2-4):413-430. https://doi.org/10.1016/j.jhydrol.2006.09.014

Arnold JG, Srinivasan R, Muttiah RS, Williams JR (1998) Large-area hydrologic modeling and assessment: part I. Model development. J Am Water Resour Assoc 34(1):73-89

Bewket W, Sterk G (2005) Dynamics in land cover and its effect on stream flow in the Chemoga watershed, Blue Nile basin, Ethiopia. Hydrol Process 19:445-458

Chiang L, Chaubey I, Gitau M, Arnold J (2010) Differentiating impacts of land use changes from pasture management in a CEAP watershed using SWAT model. Trans ASABE 53(5):1569-1584

Gassman PW, Williams JR, Wang X, Saleh A, Osei E, Hauck LM, Izaurralde RC, Flowers JD (2010) The agricultural policy/environmental eXtender (APEX) model: an emerging tool for landscape and watershed environmental analyses. Trans ASABE 53(3):711-740

Gwate O, WoyessaYali E, Wiberg D (2015) Dynamics of land cover and impact on stream flow in the Modder River Basin of South Africa: case study of a Quaternary Catchment. Int J Environ Prot Policy 3:31-38

Hamza IA, lyela A (2012) Land use pattern, climate change, and its implication for food security in Ethiopia: review. Ethiop J Environ Study Manag 5:26-31

Kassa T, Gerd F (2007) Impact of land use/cover change on stream flow: the case of Hare River watershed, Ethiopia. In: Catchment and Lake Research LARS

Legesse D, Coulomb CV, Gasse F (2003) Hydrological response of a catchment to climate and land use changes in Tropical Africa: case study South Central Ethiopia. J Hydrol 275:67-85
Mengistu KT (2009) Watershed hydrological responses to changes in land use and land cover, and management practices at Hare watershed, Ethiopia

Nash JE, Sutcliffe JV (1970) River flow forecasting through conceptual models: Part 1. A discussion of principles. J Hydrol 10:282-290

Nigusie N, Yared TA (2010) Effect of land use/land cover management on Koga reservoir sedimentation. Nile Basin Capacity Building network (NBCBN_ SEC), Hydraulics Research Institute, Cairo

Taylor SD, He Y, Hiscock KM (2016) Modelling the impacts of agricultural management practices on river water quality in Eastern England. J Environ Manage 180:147-63. https://doi.org/10.1016/j.jenvman.2016.05.002

Setegn SG, Rayner D, Melesse AM, Dargahi B et al (2011) Climate change impact on agricultural water resources variability in the northern highlands of Ethiopia. Springer Science Business Media, Berlin

Singh J, Knapp HV, Demissie M (2014) Hydrologic modeling of the Iroquois river watershed using HSPF and SWAT; ISWS CR 2004-08; Illinois State Water Survey. Champaign, IL, USA, 2004. http://www.sws.uiuc.edu/pubdo c/CR/ISWSCR2004-08.pdf. Accessed 4 April

Tufa DF, Abbulu Y, Srinivasarao GVR (2014) Watershed hydrological response to changes in land use/cover pattern of River Basin: a review. Int J Civil Struct Environ Infrastruct Eng Res Dev 4:157-170

Tuppad P, Santhi C, Williams J, Srinivasan R, Wang X, Gowda P (2010) Simulation of conservation practices using APEX model. Appl Eng Agric 26(5):779-794

Vilaysane B, Takara K, Luo P, Akkharath I, Duan W (2015) Hydrological stream flow modeling for calibration and uncertainty analysis using SWAT model in the Xedone river basin, Lao PDR. Procedia Environ Sci 28:380-390

Zhou J, Liu Y, Guo H, He D (2014) Combining the SWAT model with sequential uncertainty fitting algorithm for stream flow prediction and uncertainty analysis for the Lake Dianchi Basin, China. Hydrol Process. 28:521-533

\section{Publisher's Note}

Springer Nature remains neutral with regard to jurisdictional claims in published maps and institutional affiliations.

\section{Submit your manuscript to a SpringerOpen ${ }^{\circ}$ journal and benefit from:}

- Convenient online submission

- Rigorous peer review

- Open access: articles freely available online

- High visibility within the field

- Retaining the copyright to your article

Submit your next manuscript at springeropen.com 